\title{
The Obligation to Use Bahasa Indonesia in National Trade: A Juridical Review
}

\section{Zaid $^{1 *}$, Anggraeni Pratama Indrianto ${ }^{2}$, Fathir Arya Dimas ${ }^{3}$}

${ }^{1}$ Master of Law, Universitas Muhammadiyah Yogyakarta, Indonesia

2,3 Master of Management, Universitas Pembangunan Nasional “Veteran” Yogyakarta, Indonesia

\section{ART ICLE INFO}

Article history:

Received July 02, 2021

Revised July 03, 2021

Accepted August 16, 2021

Available online August 25, 2021

\section{Keywords:}

Label, Fair Trade, National

Trade, Omnibus Law

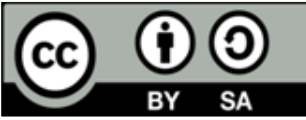

This is an open access article under the CC BY-SA license.

Copyright $\left({ }^{\circ} 2021\right.$ by Author. Published by Universitas Pendidikan Ganesha.

\begin{abstract}
A B S T RA C T
Language is one of the tools and also a communication system both orally and in writing that is used by certain people in certain countries or regions. Language is a very important essence and a very basic aspect. Therefore, every human being in various activities and life is always closely related to it. This includes trading. Considering that no research discusses the use of Bahasa Indonesia in national trade, especially after passing the omnibus law on job creation, so by using the normative juridical method, this study aims to identify and analyze the need for the use of Indonesian which has emerged as the national language and the ideal official language as part of the from national identity in national trade to achieve fair trade. This research uses a method that is built on a system of norms, rules of laws and regulations, principles, court decisions, agreements, and doctrines (teachings). The results of this study ultimately conclude that the use of Bahasa Indonesia in national trade is mandatory for every party, especially business actors in determining the inclusion of Indonesian on labels of goods and services that are distributed and traded domestically. The results of this study also suggest that every individual and business actor should not forget to include product information in the form of labels using Bahasa Indonesia. Because it can create a "win-win solution" for business actors and their consumers.
\end{abstract}

\section{INTRODUCTION}

Language is one of the tools and also a communication system both orally and in writing that is used by certain people in certain countries or regions. In cultural expression, language is a very important essence and a very fundamental aspect (Manca et al., 2019; Marchini et al., 2021). Therefore, language is not merely lingual (which is only a means of communication between two parties who use language only); but that language is also cultural (which inspires and encourages humans to a better stage in their lives; at the same time enhances human culture) (Ahmad, 1978; Mubaligh, 2010; Sweet et al., 2016). And language is also one of the most important parts of human life because every human being in various activities and life is always closely related to it. In communicating and socializing with the surrounding environment, humans use and utilize language to express and express all their thoughts. Not only that, but humans also use language in various other aspects. In short, no one in his or her life can be separated from language (Mubaligh, 2010; Shimazawa et al., 2018). Besides being used by humans in general, in particular, language is also used by the state for certain purposes. So that the state can take advantage of the function of language to achieve these interests. Indonesia is a country that notices language in all facets. Indonesia is either the country in the world that notices language in all facets. From the various home-grown languages that exist in Indonesia, Bahasa Indonesia is selected as the national and official language of Indonesia. As the national language, Indonesian is used for political, cultural, and social functions. While the official language is used for state business, national courts, parliament, to business and commerce (Ridwan, 2018; Smith \& Jarkko, 1998).

In trade, Association of Southeast Asian Nations (ASEAN) Member States (AMS) issued a Technical Competency Strengthening Project to strengthen Consumer Protection in ASEAN in the form of Product Safety and Labeling. It is stated that products that use the language of the country of origin and not the country of the sale in their labels are products that do not comply with standards and are weak and risk becoming a growing market for trade in unsafe and unhealthy products. Therefore, the use of language in trade is something very important and an interesting policy to study. Moreover, the use of Indonesian in national trade is also regulated in the omnibus law on job creation, which was just ratified last October 2020 
(Postman, 2011; Zaid et al., 2021), which no one has discussed in the literature yet. Therefore, starting from the notion construct of nationalism, this study aims to recognize and analyze the necessity of using Bahasa Indonesia that emerges as the ideal national and official language as a portion of national identity in national trade to attain fair trade. Bahasa Indonesia has a wealthy and complex chronicle as an indicator of national unification and independence that continually growing along with the escalating amount of native and second-language speakers (Oliveira et al., 2016; Postman, 2011). In the beginning, Since the earliest documented times, Malay was the original language of the society living on both sides of the Strait of Malacca which separates Sumatra from the Malacca Peninsula. As the Straits had always been a crowded sea highway, Incalculable excursionists and merchants drew on contact with its language. For centenaries, they spoke Malay throughout the islands of Indonesia and the language became a widely spoken lingua franca, especially in coastal areas. This is either of the principal grounds why in the 20th century, Malay was preferred as the national language of the Republic of Indonesia and also played such a prominent part in presiding Indonesian unity (Nugroho, 2015; Ridwan, 2018).

Bahasa Indonesia was born from the independence movement and the creation of the nation from the struggle against Dutch colonialism which led to the founding of the Republic of Indonesia in 1945. At first, Boedi Oetomo, the first Indonesian nationalist organization, promoted Malay as the national language as a rejection of the Dutch language at that time. Over time, 20 years later it was officially replaced as Indonesian in the Indonesian Youth manifesto 1928. The Youth Pledge acknowledged and pledged to always uphold the unifying language of the nation, namely Indonesian (Fitriati \& Rata, 2020). This is what makes Indonesia the only country that has succeeded in promoting the native language (Indonesian) as its postcolonial national language (Paauw, 2009). Over time, Bahasa Indonesia has served either of the most broadly spoken languages in the world. The indication is that Bahasa Indonesia is now "the language of instruction" in every national school and is broadly consented to receive as the language of government administration, media, and business for sure. Bahasa Indonesia is also used for most inter-ethnic communication (Smith-Hefner, 2009). The extraordinary elaboration and spread of Indonesian attest not only to the sociohistorical coincidence of its selection as a potential national language but also to the effectiveness of the country-dominated infrastructure in which it is spoken and propagated (Errington, 2010).

In addition, Bahasa Indonesia is also a hot topic in a lot of research literature. Several previous studies have tried to examine and assess the existence of the Bahasa Indonesia and its development in the era of globalization (Assapari, 2014; Tan, 2013). Some of them have even analyzed the potential of Indonesian to become an international language (Amin, 2021; Lopez, 2019). The implication is that Indonesian has become the most important language of the many languages in ASEAN (Adelaar, 2016). This study aims to identify and analyze the need for the use of Indonesian which has emerged as the national language and the ideal official language as part of the from national identity in national trade to achieve fair trade.

\section{METHODS}

This research uses a method that is built on a system of norms, rules of laws and regulations, principles, court decisions, agreements, and doctrines (teachings) (Dewata \& Achmad, 2019). The approach applied also uses a statutory, conceptual approach and slightly uses a historical approach to explain the history of Bahasa Indonesia. The historical approach in legal research is very important to understand the law more deeply (Arfa \& Marpaung, 2016; Rahardjo, 1986). So that this research is juridical normative by examining an object based on legal norms in-laws and regulations (law in books) (Amiruddin \& Asikin, 2012) which are based on primary and secondary legal materials (Soekanto, 1984). Primary legal materials are taken from international and national legal rules based on a normative approach. The national legal rules are taken based on the hierarchy of legislation in Indonesia, starting from the highest level, namely the 1945 Constitution, to the laws and regulations that are below it. Be it legislation, government regulations, or ministerial regulations. Meanwhile, secondary legal materials are taken and obtained from textbooks, national and international journals or articles as well as expert opinions following a literature approach.

\section{RESULTS AND DISCUSSIONS}

\section{Results}

Undang-Undang Dasar 1945 (UUD 1945) as the basis and highest law in Indonesia states in Article 36 that "The state language is Bahasa Indonesia". Bahasa Indonesia considered in the 1945 Constitution is in accordance with the youth oath pledge on October 28,1928 , as the language of unity as stated in theLaw 
of the Republic of Indonesia Number 24 of 2009 concerning the Flag, Language, and State Emblem, as well as the National Anthem. Nevertheless, Bahasa Indonesia does not close itself to development for the sake of vocabulary enrichment, stabilization and standardization of the language system, development of language barrels, and efforts to improve the function of Indonesian as an international language as explained in Article 41 paragraph (2) of Law Number 24 of 2009 concerning Flags, Language, National Emblem, and National Anthem.

The inauguration of Bahasa Indonesia as the national language and the official language of the state is not without reason, this is related to the function of language which is so important for a country and nation. It is stated in Article 25 of Law Number 24 of 2009 that Bahasa Indonesia serves as a national identity, national pride, a means of unifying various ethnic groups, as well as a means of communication between regions and regional cultures" which is going to be explained briefly but in-depth in the following; Firstly, Bahasa Indonesia as national identity. As known, language is intrinsically linked to identity, and this often includes the identity of a nation. Identity simply can be interpreted as a characteristic. In psychology, identity often refers to the identity, self-esteem, or self-image of someone or something. So that Indonesian as a nation's identity can also be interpreted that the Indonesian language is the characteristics that describe identity, self-esteem, or the image of the nation. Becoming an integral section of national identity, language represents what is extremely important to each nation, its history also its tradition, culture, or customs. Language policy, in turn, portrays any transformation (socially or politically) in every country of the world. So on that basis, Article 62 of Law Number 24 of 2009 states that every Indonesian citizen is obliged to maintain and protect the Indonesian language for the honor and sovereignty of the nation and state under this Law. And this interest is increasing in the midst of many foreign languages, which is considered a threat to Indonesian's (Foster \& Welsh, 2017; Martin-Anatias, 2018a), being introduced in Indonesia (Martin-Anatias, 2018b).

Secondly, Bahasa Indonesia as the pride of the nation. National pride is a positive influence felt by the community against their country as a yield of national identity. It is the feeling of deep pleasure or sense of respect to a person's nation and the dignity that derives from a person's national identity (Smith \& Jarkko, 1998). So, Bahasa Indonesia is a source of national pride. National pride here is assumed by social scholars as a notable phenomenon, both in itself and because of its consequences for various important topics in comparative economics and politics (Dimitrova-Grajzl et al., 2016). In addition, as explained in the explanation of Law Number 24 of 2009 that "Bahasa Indonesia even tends to develop into a language of broad communication. Its use by other nations, which tends to increase from time to time, has become the pride of the Indonesian nation". Therefore, in its occupation as an emblem of nationwide pride, the Indonesian language reflects the socio-cultural values that underlie a sense of nationality. Based on this pride, the Indonesian language must continue to be maintained, nurtured, and developed as well as a sense of pride for its users to continue to be fostered (Nugroho, 2015).

Thirdly, Bahasa Indonesia as a means of unifying various ethnic groups. In a literature, it is stated that Bahasa Indonesian language unifies about 701 ethnic languages in Indonesia (Kwary, 2019). Therefore, the 1945 Constitution (UUD) in article 1 states that the State of Indonesia is a unitary state in the form of a republic. Unity in the Unitary State of the Republic of Indonesia (NKRI) is closely related to the unity that exists in the motto "Unity in Diversity". Because the formation of the Unitary State of the Republic of Indonesia is also based on the philosophy of Pancasila, one of which is the unity of Indonesia. It's just that to achieve all of this, effective means and tools are needed to be used as instruments for development, awareness, and national unity. Apart from the flag, state symbol, and national anthem, Indonesian is the most effective instrument in achieving these goals.

The validity of Bahasa Indonesia as a unifying language of the nation has been pledged and recognized since 1928 in the youth oath. In addition, Law Number 24 of 2009 also explains that one of the objectives of Bahasa Indonesia is to "strengthen the unity and integrity of the nation and the Unitary State of the Republic of Indonesia". It is because Bahasa Indonesia is a cultural manifestation rooted in the history of the nation's struggle, unity in cultural diversity, and similarities in realizing the ideals of the nation and the Unitary State of the Republic of Indonesia. So from the explanation above, it is clear that philosophically, historically, to Indonesian law, the Bahasa Indonesia is an important instrument for the unity of the Indonesian state and the unity of the nation.

And lastly is Bahasa Indonesia as a medium of communication among regions and regional cultures. In the midst of the condition of a multilingual, multicultural and multiracial nation such as in Indonesia, communication tools and facilities are needed that can be understood and understood by every Indonesian citizen from various ethnic groups, customs, cultures, and different regions. Bahasa Indonesia as a unifying tool and means of tribes, cultures, and languages, Bahasa Indonesia allows harmony among tribes, cultures, and languages in the archipelago, without having to lose ethnic identity and loyalty to socio-cultural values 
and the background of the local language concerned. More than that, with the national language, the community can put the national interest far above the interests of the region or group.

\section{Discussion}

The function of Bahasa Indonesia as the official language of the state as stated in Article 25 paragraph 3 of Law Number 24 of 2009 states that one of them is for commercial transactions (trading). In national (domestic) trade, the use of the Bahasa Indonesia does have its own place in the eyes of the law, especially regarding product labeling. This points to the Law of the Republic of Indonesia Number 7 of 2014 concerning Trade where in Chapter IV related to domestic trade Article 6 states that "every Business Actor is obliged to use or complete Bahasa Indonesia labels on goods traded domestically".

Labels in general can be defined as writing or including information on something. The explanation in Article 6 of Law Number 7 of 2014 in more detail defines "Indonesian labels as any information (information) regarding Goods in the form of writing Bahasa Indonesia, a combination of images and writings in Bahasa Indonesia, or other forms containing information about the Goods and descriptions of the perpetrators. Business, as well as other information that is included in the Goods, is inserted into, affixed/attached to the Goods, printed on the Goods, and/or is part of the packaging of the Goods". Labels are often provided by business actors in every product they produce. However, the need for labeling is increasing when it comes to products that are consumer goods in the form of food, agricultural products, and cosmetics to medicines. So usually the use of labels is increasingly complex. Therefore, international organizations such as the "Food and Agriculture Organization (FAO), The United States Food and Drug Administration (USFSDA), Food and Drug Administration (FDA), Federal Trade Commission (FTC)", and several other organizations are aggressively making regulations and guidelines for labeling in a product.

The inclusion of information (labels) on products is also regulated in Law Number 24 of 2009 in Article 37 paragraph 1 and it is stated in Article 39 paragraph 1 of Presidential Regulation Number 63 of 2019 concerning the Use of Bahasa Indonesia that "Bahasa Indonesia must be used in information about goods or services. Domestic or foreign production services circulating in Indonesia". This provision was then reaffirmed in the omnibus Law Number 11 of 2020 on Job Creation where in Article 46 which has amended the provisions of Article 6 (1) of Law Number 7 of 2014 concerning Trade (State Gazette of the Republic of Indonesia Year 2014 Number 45, Supplement to the State Gazette of the Republic of Indonesia Number 5512) it is stated that "Every Business Actor is obliged to use or complete a Bahasa Indonesia label on goods traded domestically".

So based on the two articles above, two conclusions can be drawn. Firstly, whether in the form of goods or services, every product must include information related to the product (label). The label then becomes one of the fundamental resources that function to promote and inform everything needed (properly) related to the product or service of that particular product (Shimazawa et al., 2018). Then secondly, it is clear that it is obligatory to use the Bahasa Indonesia in product labels when the product (goods or services) is produced or imported for trade in the national (domestic) market in accordance with Article 2 of the Regulation of the Minister of Trade of the Republic of Indonesia Number 73/M-Dag/Per/ 9/2015 concerning the Obligation to Affix Labels in the Bahasa Indonesia on Goods. Language can be categorized as an apprehensible and inapprehensible language (Heix \& Holzmüller, 2019). And the use of Bahasa Indonesia is certainly a potential strategy so that every information in the product can be well understood by consumers (Malhotra et al., 2017).

Therefore, considering that only a few (not many) labeled products provide an accurate and complete message in the required language (Sweet et al., 2016). This study, in essence, agrees with previous research which states that it is important to have information asymmetry between producers and consumers (Marchini et al., 2021), and recommend improving labeling policies to disclose honest and valid product information to consumers (Alsmadi \& Khizindar, 2015). Obviously, by developing clearer language (in this case Indonesian) for product information statements (Manca et al., 2019). Therefore, this study result is also similar to previous research which states that consumers will tend to prefer label language that is easy to understand (Choi et al., 2018). As previous research has shown that a lack of ability to understand language will only add to the great difficulty of information processing (Harzing \& Feely, 2008). Not only that, but previous literature also revealed that the use of understandable language, in product labeling, will affect "consumers' attention, trust, perceived quality, taste perception, and purchase intention" (Ho et al., 2019) to purchase decision (Oliveira et al., 2016). And this is due to consumer knowledge of the product and trust in the information presented clearly and easily understood (Rupprecht et al., 2020). So of course, this strategy will not only save business actors from legal consequences but will also be very profitable.

However, this does not mean that the label on a product must be in Indonesian as a whole. Involving or including a foreign language or regional language is still allowed by law under two conditions. First, as a 
complement (which means it is used as needed) as stated in Article 37 (2) of Law Number 24 of 2009 and Article 39 (5) of Presidential Regulation Number 63 of 2019 concerning the Use of the Bahasa Indonesia. Second, if it does not exist or cannot be created or found its equivalent based on Article 3 (2) of the Regulation of the Minister of Trade of the Republic of Indonesia Number 73/M-Dag/Per/9/2015. And interestingly, previous research has found that the use of a combined language with a foreign language is actually more chosen and preferred by consumers (Yener \& Taşçığlu, 2020). but it must remain carefully because this kind of method can also result in a decrease in product quality or even violate the law (Rimpeekool et al., 2015).

In essence, this study implies that the use of Bahasa Indonesia in product labeling is very important for any business actor who wants to trade and do business in the country. Due to its mandatory nature, therefore, violations in this matter have criminal sanctions as stipulated in the omnibus Law Number 11 of 2020 on Job Creation Article 46 which has amended Article 104 of Law Number 7 of 2014 concerning Trade "is punished with imprisonment for a maximum of 5 (five) years or a fine of a maximum IDR $10,000,000,000.00$ (ten billion rupiah)". On the other hand, this study also implies that the use of Indonesian in national trade which is packaged in a label is also a "win-win solution" for business actors and their consumers. Where business actors will avoid legal entanglements and also get potential material benefits, at the same time, consumers will also benefit by getting their rights of correct, clear, and honest information as stated in the United Nations Guidelines for Consumer Protection (2016) and Article 3 of Law number 8 1999 concerning Consumer Protection.

\section{CONCLUSION}

Referred to the results and discussion above, it can be resumed that Indonesian is the national language as well as the official language of the state as stated in the 1945 Constitution. This implies that the use of Indonesian must be applied in various aspects of life and activities. One of them is trading. The proceeds of the juridical study assert that the use of the Bahasa Indonesia is an obligation for anyone who wants to trade in Indonesia. One of the uses of Bahasa Indonesia in national trade is to include it on product labels, both goods, and services that are circulated or traded in the country. It is regulated in the omnibus law on job creation and the law on trade. This obligation has consequences and is punishable by a fine and imprisonment which is a maximum imprisonment of 5 (five) years or a maximum fine of IDR $10,000,000,000.00$ based on the new provisions regulated in the omnibus law on job creation. The results of this study also suggest that every individual and business actor should not forget to include product information in the form of labels using Bahasa Indonesia. Because it can create a "win-win solution" for business actors and their consumers. Where business actors will avoid legal entanglements and also get potential material benefits, on the other hand, consumers will also benefit by getting their rights as consumers. In addition, the researcher also hopes that this research can provide benefits in the form of providing knowledge and adding new insights, especially for writers and also for readers. This research can also be used as material or as a reference for other researchers who conduct similar research, development, or continuation related to the Bahasa Indonesa and also national trade.

\section{REFERENCES}

Adelaar, A. (2016). Dialects of Malay/Indonesian. The Handbook of Dialectology, 571-581. https://doi.org/10.1002/9781118827628.CH36.

Ahmad, M. A. B. (1978). Peranan Bahasa Dalam Kebudayaan. Singapore Journal of Education, 1(1), 34-36. https://doi.org/10.1080/02188797808548518.

Alsmadi, S., \& Khizindar, T. (2015). Consumers' perceptions of consumer rights in Jordan. International Journal of Commerce and Management, 25(4), 512-530. https://doi.org/10.1108/IJCOMA-022013-0011.

Amin, K. F. (2021). Pengajaran Bahasa Indonesia untuk Penutur Asing (BIPA) dan Pengenalan Budaya Lokal Bugis-Makassar. Jurnal Pendidikan Indonesia, 2(6), 1044-1053. https://doi.org/10.5614/SOSTEK.ITBJ.2015.14.1.2.

Amiruddin, \& Asikin, Z. (2012). Pengantar Metode Penelitian Hukum. Raja Grafindo Persada.

Arfa, F. A., \& Marpaung, W. (2016). Metodologi Penelitian Hukum Islam (Revisi). Pernadamedia Group.

Assapari, M. M. (2014). Eksistensi Bahasa Indonesia Sebagai Bahasa Nasional Dan Perkembangannya Di Era Globalisasi. Prasi: Jurnal Bahasa, Seni, Dan Pengajarannya, 9(18), 29-37. https://doi.org/10.23887/PRASI.V9I18.8943.

Choi, S., Liu, S. Q., \& Mattila, A. S. (2018). Consumer Response to Authentic-Language Versus EnglishLanguage Menu Labeling in Ethnic Dining. Cornell Hospitality Quarterly, 59(2), 125-134. 
https: //doi.org/10.1177/1938965517730314.

Dewata, M. F. N., \& Achmad, Y. (2019). Dualisme Penelitian Hukum Normatif dan Empiris (Cetakan V) (Pustaka Pelajar (ed.)).

Dimitrova-Grajzl, V., Eastwood, J., \& Grajzl, P. (2016). The longevity of national identity and national pride: Evidence from wider Europe. Research and Politics, 3(2), 1-9. https: //doi.org/10.1177/2053168016653424.

Errington, J. J. (2010). On the Ideology of Indonesian Language Development: The State of a Language of State. Pragmatics, 2(3), 417-426.

Fitriati, S. W., \& Rata, E. (2020). Language, Globalisation, and National Identity : A Study of English-Medium Policy and Practice in Indonesia. Journal of Language, Identity and Education, 20(6), 411-424. https: //doi.org/10.1080/15348458.2020.1777865.

Foster, M., \& Welsh, A. (2017). The controversial code-switching of an Indonesian president. South East Asia Research, 25(4), 395-411. https://doi.org/10.1177/0967828X17740459.

Harzing, A. W., \& Feely, A. J. (2008). The language barrier and its implications for HQ-subsidiary relationships. Cross Cultural Management: An International Journal, 15(1), 49-61. https: //doi.org/10.1108/13527600810848827.

Heix, S., \& Holzmüller, H. (2019). Effects of Double Language Labeling in the Context of FMCG-Products: A Mixed-Methods Approach: An Abstract. In S. Wu, F. Pantoja, \& N. Krey (Eds.), Marketing Opportunities and Challenges in a Changing Global Marketplace (pp. 529-530). Springer. https://doi.org/10.1007/978-3-030-39165-2_218.

Ho, H.-C., Chiu, C. L., Jiang, D., Shen, J., \& Xu, H. (2019). Influence of Language of Packaging Labels on Consumers' Buying Preferences. Journal of Food Products Marketing, 25(4), 435-461. https://doi.org/10.1080/10454446.2019.1572562.

Kwary, D. A. (2019). A corpus platform of Indonesian academic language. SoftwareX, 9, 102-106. https://doi.org/10.1016/J.SOFTX.2019.01.011.

Lopez, L. G. M. (2019). The Indonesian language and its potential to become an international language. Advances in Social Science, Education and Humanities Research, 279, 278-280. https: //doi.org/10.2991/ICALC-18.2019.40.

Malhotra, R., Bautista, M. C., Tan, N., Tang, W., Tay, S., Tan, A., Pouliot, A., \& Vaillancourt, R. (2017). Add A Language! Add A Picture!-Improving Prescription Medication Labels For Elderly Singaporeans. Innovation in Aging, 1(suppl_1), 968-968. https://doi.org/10.1093/GERONI/IGX004.3494.

Manca, T. A., Graham, J. E., Dubé, È., Kervin, M., Castillo, E., Crowcroft, N. S., Fell, D. B., Hadskis, M., Mannerfeldt, J. M., Greyson, D., MacDonald, N. E., \& Top, K. A. (2019). Developing product label information to support evidence-informed use of vaccines in pregnancy. Vaccine, 37(48), 71387146. https://doi.org/10.1016/J.VACCINE.2019.09.063.

Marchini, A., Riganelli, C., Diotallevi, F., \& Polenzani, B. (2021). Label information and consumer behaviour: evidence on drinking milk sector. Agricultural and Food Economics, 9(1), 1-24. https: //doi.org/10.1186/S40100-021-00177-5.

Martin-Anatias, N. (2018a). Language selection in the indonesian novel: Bahasa gado-gado in expressions of love. South East Asia Research, 26(4), 347-366. https://doi.org/10.1177/0967828X18809592.

Martin-Anatias, N. (2018b). Bahasa gado-gado: English in Indonesian popular texts. World Englishes, 37(2), 340-355. https://doi.org/10.1111/WENG.12313.

Mubaligh, A. (2010). Relasi Bahasa Dan Ideologi. LiNGUA: Jurnal Ilmu Bahasa Dan Sastra, 5(2), 112-118. https://doi.org/10.18860/LING.V5I2.622.

Nugroho, A. (2015). Pemahaman Kedudukan Dan Fungsi Bahasa Indonesia Sebagai Dasar Jiwa Nasionalisme. Prosiding Seminar Nasional Bulan Bahasa UNIB, 285-291.

Oliveira, D., Machín, L., Deliza, R., Rosenthal, A., Walter, E. H., Giménez, A., \& Ares, G. (2016). Consumers' attention to functional food labels: Insights from eye-tracking and change detection in a case study with probiotic milk. LWT - Food Science and Technology, 68, 160-167. https://doi.org/10.1016/J.LWT.2015.11.066.

Paauw, S. (2009). One Land, One Nation, One Language: An Analysis of Indonesia's National Language Policy. University of Rochester Working Papers in the Language Sciences, 5(1), 2-16.

Postman, W. A. (2011). Some critical concerns for adapting the Bilingual Aphasia Test to Bahasa Indonesia. $\begin{array}{llll}\text { Clinical Linguistics } & \text { 25(6-7), }\end{array}$ https://doi.org/10.3109/02699206.2011.566665.

Rahardjo, S. (1986). Ilmu Hukum. PT. Citra Aditya Bakti.

Ridwan, M. (2018). National and Official Language: The Long Journey of Indonesian Language. Budapest International Research and Critics Institute (BIRCI-Journal): Humanities and Social Sciences, 1(2), 72-78. https://doi.org/10.33258/BIRCI.V1I2.14. 
Rimpeekool, W., Seubsman, S. ang, Banwell, C., Kirk, M., Yiengprugsawan, V., \& Sleigh, A. (2015). Food and nutrition labelling in Thailand: a long march from subsistence producers to international traders. Food Policy, 56, 59-66. https://doi.org/10.1016/J.FOODPOL.2015.07.011.

Rupprecht, C. D. D., Fujiyoshi, L., McGreevy, S. R., \& Tayasu, I. (2020). Trust me? Consumer trust in expert information on food product labels. Food and Chemical Toxicology, 137, 111170. https: //doi.org/10.1016/J.FCT.2020.111170.

Shimazawa, R., Kano, Y., \& Ikeda, M. (2018). Natural language processing-based assessment of consistency in summaries of product characteristics of generic antimicrobials. Pharmacology Research \& Perspectives, 6(6), e00435. https://doi.org/10.1002/PRP2.435.

Smith-Hefner, N. (2009). Language and national identity in Asia. Journal of Multilingual and Multicultural Development, 30(4), 363-365. https://doi.org/10.1080/01434630802597888.

Smith, T. W., \& Jarkko, L. (1998). National Pride: A Cross-national Analysis. GSS Cross-National Report, 19, $1-47$.

Soekanto, S. (1984). Pengantar Penelitian Hukum. UI Press.

Sweet, L., Pereira, C., Ford, R., Feeley, A. B., Badham, J., Mengkheang, K., Adhikary, I., Gueye, N. Y. S., Coly, A. N., Makafu, C., \& Zehner, E. (2016). Assessment of corporate compliance with guidance and regulations on labels of commercially produced complementary foods sold in Cambodia, Nepal, Senegal and Tanzania. Maternal and Child Nutrition, 12, 106-125. https://doi.org/10.1111/MCN.12268.

Tan, M. (2013). Assessing Bahasa Melayu and Bahasa Indonesia. The Companion to Language Assessment, 1873-1891. https://doi.org/10.1002/9781118411360.WBCLA111.

Yener, D., \& Taşçığlu, M. (2020). Does the Use of Foreign Languages in Different Types of Products Lead to Different Consumer Perception? Journal of International Consumer Marketing. https: //doi.org/10.1080/08961530.2020.1863168.

Zaid, Z., Dawaki, F. A., \& Ololade, S. K. (2021). Should the State Control Tariffs? Journal of Governance and Public Policy, 8(1), 22-36. https://doi.org/10.18196/JGPP.811340. 